\title{
Cost-competitiveness of organic photovoltaics for electricity self-consumption at residential buildings: A comparative study of Denmark and Greece under real market conditions
}

\author{
Chatzisideris, Marios Dimos; Laurent, Alexis; Christoforidis, Georgios C.; Krebs, Frederik C
}

Published in:

Applied Energy

Link to article, DOI:

10.1016/j.apenergy.2017.10.003

Publication date:

2017

Document Version

Peer reviewed version

Link back to DTU Orbit

Citation (APA):

Chatzisideris, M. D., Laurent, A., Christoforidis, G. C., \& Krebs, F. C. (2017). Cost-competitiveness of organic photovoltaics for electricity self-consumption at residential buildings: A comparative study of Denmark and Greece under real market conditions. Applied Energy, 208, 471-479.

https://doi.org/10.1016/j.apenergy.2017.10.003

\section{General rights}

Copyright and moral rights for the publications made accessible in the public portal are retained by the authors and/or other copyright owners and it is a condition of accessing publications that users recognise and abide by the legal requirements associated with these rights.

- Users may download and print one copy of any publication from the public portal for the purpose of private study or research.

- You may not further distribute the material or use it for any profit-making activity or commercial gain

- You may freely distribute the URL identifying the publication in the public portal 
Chatzisideris MD, Laurent A, Christoforidis GC, Krebs FC. Cost-competitiveness of organic photovoltaics for electricity self-consumption at residential buildings: A comparative study of Denmark and Greece under real market conditions. Appl Energy 2017;208:471-9. doi:10.1016/j.apenergy.2017.10.003.

\section{Cost-competitiveness of organic photovoltaics for electricity}

\section{self-consumption at residential buildings: A comparative study}

\section{of Denmark and Greece under real market conditions}

Marios D. Chatzisideris ${ }^{\mathrm{a}, *}$, Alexis Laurent ${ }^{\mathrm{b}}$, Georgios C. Christoforidis ${ }^{\mathrm{c}}$, Frederik C. Krebs ${ }^{\text {a }}$

a Department of Energy Conversion and Storage, Technical University of Denmark, Roskilde, Denmark

${ }^{\mathrm{b}}$ Division for Quantitative Sustainability Assessment, Department of Management Engineering, Technical University of Denmark, Lyngby, Denmark

${ }^{\mathrm{c}}$ Department of Electrical Engineering, Western Macedonia University of Applied Sciences, Kozani, Greece

* corresponding author: madc@dtu.dk

\section{ABSTRACT}

To address sustainability challenges, photovoltaics (PV) are regarded as a promising renewable energy technology. Decreasing PV module costs and increasing residential electricity prices have made self-consumption of PV-generated electricity financially more attractive than exporting to the 
grid. Organic photovoltaics (OPV) are an emerging thin-film PV technology that shows promise of greatly improving the environmental and economic performances of PV technologies. Previous studies have estimated the current and future costs of OPV technologies, but the attractiveness of investing in OPV systems has not been evaluated under real market conditions, especially under PV self-consumption schemes. In this study, we investigate the self-consumption of electricity generation from conventional and organic PV systems installed at residential houses in two different countries, Denmark and Greece, under current PV regulatory frameworks. We then focus on modelling and assessing the cost-competitiveness of organic PV technologies based on cost estimations for existing pilot-scale (kW-range), and projected scale-up (100MW) and industrial-scale (100GW) manufacturing capacity levels. Our generic results applying to all PV technologies show that PV systems installed at residential houses in Greece perform economically better than those in Denmark do in terms of self-sufficiency and gross electricity bill savings (i.e. excluding PV costs). Using the two country cases, which present very different settings, we characterise and discuss the influence of three key parameters of the economic performance of PV systems, namely the PV regulatory scheme, the solar irradiation level and the temporal match between the electricity consumption and solar irradiation profiles. Focusing on organic PV systems developed in an industrial-scale cost setting (1.53 €/Wp), we find that they deliver significant electricity bill savings for residential houses in Greece (38\%) under current conditions, while they may not be sufficiently attractive for residential houses in Denmark $(6.5 \%)$ due to mainly the different PV regulatory schemes. Based on these findings, we therefore recommend investors interested in renewable energy technologies to pursue scaling up the manufacturing capacity of OPV technologies, as well as assess a large number of countries to identify and prioritise financially attractive settings for PV self-consumption.

Keywords: organic photovoltaics; self-consumption; net-metering; cost optimization 


\section{Introduction}

Solar photovoltaics (PV) are seen globally as one of the most promising technologies in the race again climate change [1]. In the European context, PV systems are expected to play a key role in improving the energy performance of the building sector (Directive 2012/27/EU) despite the operation management challenges associated with large-scale penetration of renewable energy sources at residential [2] and industrial level [3], the integration of energy storage and electric vehicles [4], and load management by active end users [5].

In recent years, continuously declining PV module costs, in combination with rising residential electricity prices and fading feed-in tariffs, have made self-consumption of PV-generated electricity financially more attractive than exporting to the grid [6-8]. Nevertheless, PV-generated electricity costs are still not low enough to compete on the electricity market, but depend on state support through self-consumption and net-metering schemes [7]. If PV are to compete on the market against established electricity generation technologies, like fossils or wind power, further cost reductions are thus needed. Following these trends, a growing number of recent studies in the literature has been assessing the self-consumption of PV-generated electricity and its economics, as in PV only systems or in combination with battery storage (see review by Luthander [9]) [10-15].

Organic photovoltaics (OPV) are an emerging thin-film PV technology that shows promise of greatly improving the environmental and economic performance of PV technologies [16]. OPV utilize abundant, non-toxic organic molecules or polymer materials to absorb light and convert it to electricity [17], and are typically built in multiple layers that are deposited on plastic foil by low energy and high-throughput printing and coating techniques (see reviews by Krebs [18] and by Wang et al. [19]). Applications of OPV technologies have been demonstrated by previous studies, for example a pilot-scale OPV solar park installed in Denmark [20,21] and a portable solar charger, HeLi- 
on [22]. In terms of environmental impact assessment, OPV technologies have shown the potential to lower life-cycle environmental impacts compared to conventional silicon-based PV technologies, ranging from $32 \%$ to $98 \%$ depending on the environmental impact category (e.g. climate change, acidification, toxic effects on human and environment, etc.) [23].

Until now, OPV module costs have not been able to compete at market level due to shorter lifetimes and lower power conversion efficiencies. Early studies of OPV economics have focused on preliminary cost estimates [24-26] or have calculated cost targets and financial indicators [27-29] (see summaries of findings by Mulligan et al. [30] and Gambhir et al. [31]). More recent studies have projected commercial-scale production costs based on real data from pilot-scale production [30-33]. More specifically, Machui et al. [32] have estimated that, under an industrial processing scenario, costs of OPV modules could reach $0.05-0.6 € / \mathrm{Wp}$ (depending on achieved efficiency, material choice and structure), thus outperforming conventional PV technologies. Also, Gambhir et al. [31] have showed that at a conservative estimate OPV can have closely comparable levelised cost of electricity (LCOE) values to established PV technologies, while estimates at the more optimistic end showed that OPV costs can be more than 50\% lower than costs of established PV technologies [31]. Although previous studies have assessed OPV costs and compared them with costs of established PV technologies, the attractiveness of investing in OPV under real market conditions has not been researched until now. Hence, do OPV technologies offer an attractive investment for households, especially in a context where government support is decreasing and PV regulatory frameworks are gradually transitioning from feed-in-tariff to self-consumption schemes?

The goal of this study is to address this question, and evaluate the competitiveness of current and potential future costs of OPV systems installed on household roofs with a 20-year investment period under the current self-consumption frameworks using Denmark and Greece as case studies. The two countries present an interesting comparison as they offer different contextual settings (e.g. PV 
regulatory framework, solar energy availability, renewable energy policy, etc.) as explained later in the paper. Even though the scope of the study has a strong focus on OPV systems, the developed methodology and the detailed analysis of the regulatory and market frameworks for PV are generic and apply to all PV technologies.

\section{Methods and materials}

\subsection{Overall methodology}

Figure 1 shows the methodology and the associated steps adopted to assess the costcompetitiveness of OPV self-consumption. These steps are described in the following Sections and can be applied to any national setting. They include:

1. A comprehensive study of the Danish and Greek regulatory frameworks for residential PV installations served as a basis for identifying modelling and data requirements, e.g. PV regulations and possible installation capacity limits, technical specifications of electricity netting, electricity billing and remuneration schemes, etc. (Section 2.2);

2. The modelling of the PV system electricity flows was required to calculate electricity selfconsumption, exports and imports between the PV system and the grid (Section 2.3);

3. The electricity bill savings from installing an OPV system were calculated based on current electricity bill tariffs/components and available electricity price projections (Section 2.4);

4. The OPV costs were estimated based on available literature and own assumptions (Section 2.5);

5. The profitability of investing in an OPV system was evaluated based on the Net Present Value (NPV) method and trial-and-error runs (Section 2.6). 


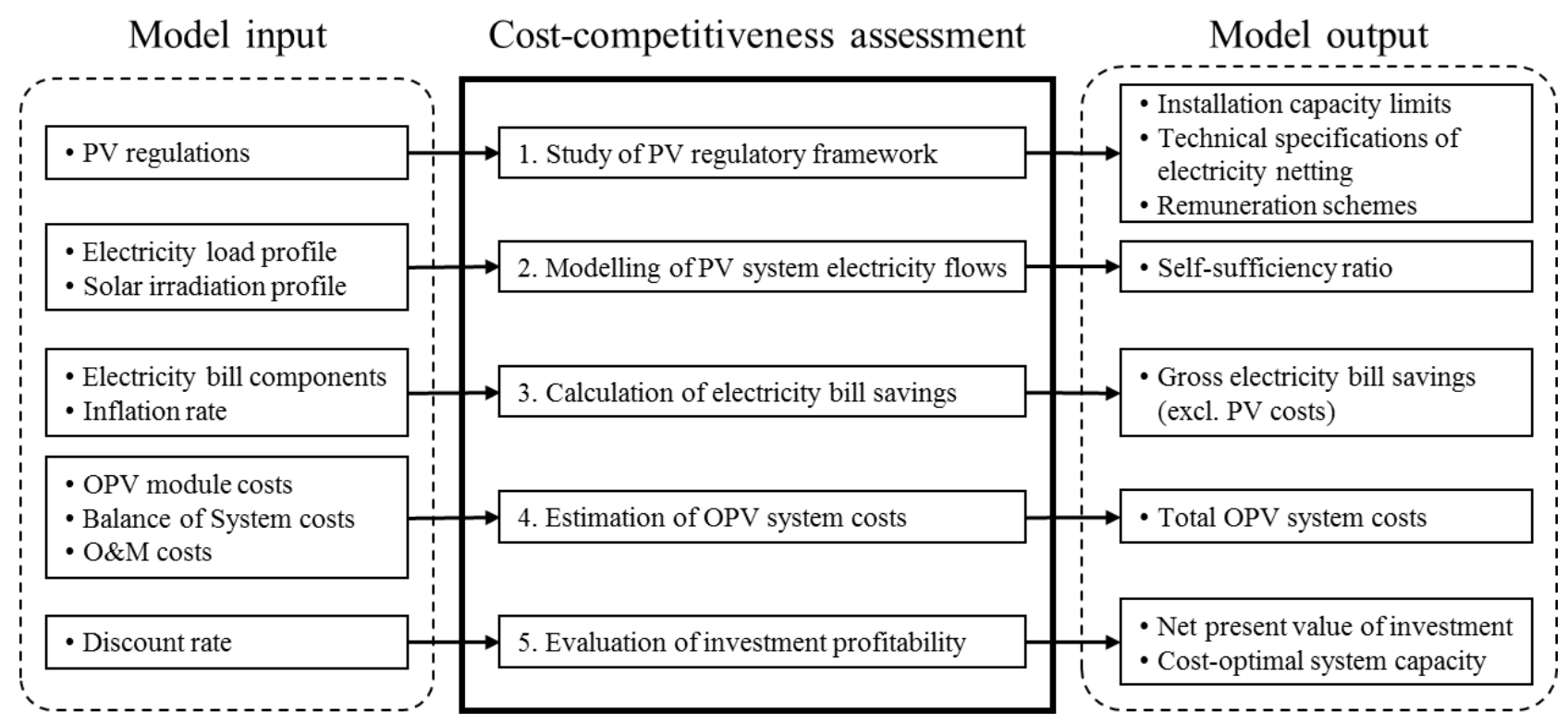

Figure 1. Steps taken and key model input and output to assess the cost-competitiveness of OPV selfconsumption in this study

\subsection{Danish and Greek regulatory frameworks for PV self-consumption}

The two countries offer an interesting comparison due to different contextual settings (e.g. solar energy availability, renewable energy policy, PV regulatory framework, etc.). Denmark is located in northern Europe with relatively low solar energy availability (i.e. $1000 \mathrm{kWh} / \mathrm{m}^{2}$ ), whereas Greece is part of southern Europe with abundance of solar energy resources $\left(1700 \mathrm{kWh} / \mathrm{m}^{2}\right)$. In terms of renewable energy integration, Denmark is one of the leaders in next-generation wind and solar power as well as and energy system transformation according to the International Energy Agency [34]. However, Greece has not yet exploited its great potential for integrating wind and solar power [35].

In terms of PV regulatory framework, Denmark and Greece have relied on attractive feed-in-tariff schemes to support the adoption of PV systems in past years. At present, the focus of PV regulatory frameworks in both countries is to support the installation of PV systems for self-consumption of PVgenerated electricity enabling consumers to lower their electricity bill costs. More specifically, net- 
metering schemes are in place under which excess generated electricity can be exported to the grid and credited to the consumer for consumption at a different time when PV generation is not sufficient to cover electricity consumption [8]. The time period for netting PV generation and electricity consumption is one hour for Denmark [36] and one year for Greece [37]. In both countries, there is no compensation for excess exported electricity to the grid after netting. In Denmark, the transmission grid operator 'Energinet' is responsible for handling the administrative tasks of PV systems, and provides detailed information and technical guidance to consumers and potential PV owners [36]. In Greece, the distribution grid operator 'HEDNO' (Hellenic Electricity Distribution Network Operator) holds a similar administrative role [38], while the Greek PV regulatory framework has been described previously in the study by Christoforidis et al. [37].

\subsection{Modelling of PV system electricity flows}

A model was developed to simulate the flows of electricity at an average residential electricity consumer with an OPV installation enabling self-consumption. Time series data sets of electricity consumption and solar irradiation values were created for a typical year and were used as inputs to the model. For the modelling of the electricity flows, the same typical year was assumed and replicated during the 20-year time horizon (2017-2036) of the OPV system model.

For Denmark, the electricity consumption data were modelled based on hourly load profiles from the year 2012 developed by the Danish Energy Association [39], as in the study by Andersen et al. [40]. The solar irradiation profile (annual irradiation level at $1000 \mathrm{kWh} / \mathrm{m}^{2}$ ) was taken from the Danish

Design Reference Year data set representing a typical meteorological year in Denmark and specifically developed for energy-related simulations [41]. 
For Greece, the electricity consumption data were modelled based on 15-minute load profiles, consisting of average consumption data from a sample of 29 residential consumers located in the Thessaloniki area referring to the year 2014 [37]. The solar irradiation profile (annual irradiation level at $1700 \mathrm{kWh} / \mathrm{m}^{2}$ ) was taken from EU's Photovoltaic Geographical Information System [42].

Electricity consumption was assumed at $4000 \mathrm{kWh} / \mathrm{year}$ as representative of one-family households without electrical heating in Denmark [43] and Greece [37]. The solar irradiation data was used to calculate the electricity generation from the OPV system assuming a horizontal-plane installation, a range of installed capacity values between 1 and $10 \mathrm{kWp}$ (typical of residential PV systems) and a $80 \%$ performance ratio (PR) [44], as explicated in Equation 1:

$O P V_{\text {generation }}=$ solar irradiation $*$ installed capacity $* P R$

To simulate the flows of electricity, the time series data sets of OPV generation and electricity consumption were compared on a time-step basis (hourly for Denmark, 15-min for Greece). In this comparison, two simple rules were followed: (i) if OPV generation was lower than consumption, the deficit was imported by the grid; and (ii) if OPV generation was higher than consumption, the surplus was exported to the grid. Based on this comparison, the total amounts of self-consumed OPV generation as well as electricity imports and exports were calculated over one typical year (i.e. each year within the period 2017-2036).

Moreover, this enabled to calculate the self-sufficiency (SS), which is a commonly used metric to describe how PV generation can cover the electricity needs of the place where it is installed, and is defined as the ratio of the self-consumed PV generation to the electricity consumption over a year [7,9]. In our current study, the scope of self-sufficiency was broadened to offer regulatory and economic perspectives, and covered not only the physically self-consumed PV generation but the 
total amount of PV generation equal to electricity consumption within the netting period over a year [8]. Therefore, in this study, self-sufficiency was calculated according to Equation 2:

$S S=\frac{\text { total } P V \text { generation equal to electricity consumption during the netting period }}{\text { electricity consumption }}$

\subsection{Calculation of gross electricity bill savings from PV self-consumption}

In this step, gross electricity bill savings (i.e. excluding PV system costs) were calculated as the difference in the electricity bill between a household with PV for self-consumption and a household without PV installation over the 20-year investment period. This was a generic calculation and applied to all PV technologies.

The electricity bill components, tariffs and different types of charges are described in Table 1 for Denmark and Table 2 for Greece. As in most European countries, the electricity bill components are divided in:

- electricity supply charges which reflect the electricity generation cost paid to the electricity supply company under competitive market conditions,

- transmission and distribution grid charges corresponding to the cost of using the electricity grid and are paid to the transmission system and the distribution system operators,

- other charges, such as taxes to the state e.g. value added tax, financing renewable energy support schemes, etc.

More specifically, for a household with PV self-consumption in Denmark, all electricity bill components described in Table 1 (for a detailed description, see the report by Kitzing et al.[45]) were calculated based on the net electricity imports except for the feed-in charge (based on the net electricity exports), the distribution grid tariff (based on the gross electricity imports) and the reduced 
Public Service Obligations (PSO) tariff (based on the self-consumption). Also, after the initial year 2017, all tariffs and charges in Denmark were assumed to increase by $1.97 \%$ annually following the inflation rate [46] unless specified otherwise (estimated inflation rate at 1.97\% [47]).

For a household in Greece (for a detailed description, see study by Christoforidis et al. [37]), the 'Special Duty' was calculated based on the total charges (before VAT) excluding the 'Special Duty for Renewables', and the VAT was calculated based on the total charges excluding the 'Special Duty'. In the case of PV self-consumption, the electricity tariff was calculated based on the net electricity imports, the Services of General Interest was calculated based on the total electricity consumption (i.e. $4000 \mathrm{kWh} / \mathrm{year}$, while all other charges were calculated based on the gross electricity imports. Moreover, after the initial year 2017, all tariffs and charges in Greece were assumed to increase annually following the inflation rate (assumed inflation rate at 2\%) except for the 'Other Charges', as in earlier studies [37].

Table 1. Electricity bill components, tariffs and fees for residential electricity consumers with/without PV self-consumption in Denmark over the investment period of 2017-2036 (1 DKK=0.13 EUR).

\section{Electricity bill components Tariffs/fees in 2017}

\section{Tariff/fees between 2018-2036}

\section{Electricity supply charges}

Subscription fee

Electricity spot price

Mark-up

$$
3.02 € / \text { month [48] }
$$

$0.0248 € / \mathrm{kWh}[46]$

$0.00798 € / \mathrm{kWh}$ (calculated

as the difference between

the retail electricity price

[48] and the spot price [46] annual increase by $1.97 \%$ following inflation Spot prices projection by DEA [46] annual increase by $1.97 \%$ following inflation 


\begin{tabular}{|c|c|c|}
\hline \multicolumn{3}{|c|}{ Transmission and distribution grid charges } \\
\hline Transmission grid tariff & $0.0108 € / \mathrm{kWh}[49]$ & annual increase by $1.97 \%$ following inflation \\
\hline Distribution grid tariff & $0.0403 € / \mathrm{kWh}[50]$ & annual increase by $1.97 \%$ following inflation \\
\hline Distribution grid & $4.03 € /$ month $[50]$ & annual increase by $1.97 \%$ following inflation \\
\hline \multicolumn{3}{|l|}{ subscription fee } \\
\hline Public Service Obligations & $0.021 € / \mathrm{kWh}[49]$ & annual decrease by $0.004186 € / \mathrm{kWh}(20 \%$ of \\
\hline (PSO) tariff & & 2017 value) and phased out by Jan $1^{\text {st }} 2022$ \\
\hline Electricity tax & $0.118 € / \mathrm{kWh}[49]$ & annual increase by $1.97 \%$ following inflation \\
\hline Value Added Tax (VAT) & $25 \%$ & $25 \%$ \\
\hline \multicolumn{3}{|c|}{ Additional charges for PV self-consumption } \\
\hline Feed-in charge & $0.000390 € / \mathrm{kWh}[49]$ & annual increase by $1.97 \%$ following inflation \\
\hline Availability payment & $0.728 € /$ month [49] & annual increase by $1.97 \%$ following inflation \\
\hline Reduced PSO tariff & $0.00039 € / \mathrm{kWh}[49]$ & annual decrease by $0.000078 € / \mathrm{kWh}(20 \%$ of \\
\hline & & 2017 value) and phased out by Jan $1^{\text {st }} 2022$ \\
\hline
\end{tabular}

Table 2. Electricity bill components, tariffs and fees for residential electricity consumers with/without PV self-consumption in Greece over the investment period of 2017-2036. A typical 3phase electricity connection was assumed with a $25 \mathrm{kVA}$ capacity.

\section{Electricity bill components Tariffs/fees in $2017 \quad$ Tariff/fees between 2018-2036}

\section{Electricity supply charges}

Subscription fee

$4.80 € /$ quarter [51] annual increase by $2 \%$ following inflation

Electricity tariff

$0.0946 € / \mathrm{kWh}[51] \quad$ annual increase by $2 \%$ following inflation

\section{Regulated charges}

Transmission grid fee annual increase by $2 \%$ following inflation 


\begin{tabular}{|c|c|c|}
\hline Transmission grid tariff & $0.00527 € / \mathrm{kWh}[51]$ & annual increase by $2 \%$ following inflation \\
\hline Distribution grid fee & $0.54 € / \mathrm{kVA} /$ year [51] & annual increase by $2 \%$ following inflation \\
\hline Distribution grid tariff & $0.0213 € / \mathrm{kWh}[51]$ & annual increase by $2 \%$ following inflation \\
\hline Services of General Interest & $0.00699 € / \mathrm{kWh}[51]$ & annual increase by $2 \%$ following inflation \\
\hline Special Duty for Renewables & $0.02477 € / \mathrm{kWh}[51]$ & annual increase by $2 \%$ following inflation \\
\hline Other Charges & $0.00007 € / \mathrm{kWh}[51]$ & $0.00007 € / \mathrm{kWh}[37]$ \\
\hline \multicolumn{3}{|l|}{ Duties and Taxes } \\
\hline Special Consumer Tax & $0.0022 € / \mathrm{kWh}[51]$ & annual increase by $2 \%$ following inflation \\
\hline Special Duty & $0.5 \%[51]$ & $0.5 \%$ \\
\hline Value added tax & $13 \%$ & $13 \%$ \\
\hline
\end{tabular}

\subsection{OPV system cost scenarios}

The lifetime costs of the OPV systems were calculated based on the cost analyses by Machui et al. [32] and Gambhir et al. [31] and complemented by additional assumptions - see Table 3. Following the approach by Machui et al. [32], three manufacturing capacity levels were considered for estimating OPV module costs: (i) a pilot-scale cost analysis with actual process data based on a kWrange OPV manufacturing capacity level; (ii) a scale-up cost projection estimating module costs based on a 100 MW OPV manufacturing capacity level; and (iii) an industrial-scale cost projection estimating module costs based on a $100 \mathrm{GW}$ OPV manufacturing capacity level. In terms of OPV module types, single devices based on P3HT:PCBM active layer materials were considered for the pilot-scale scenario [32] and MH301:PCBM with carbon electrodes for the scale-up scenario and industrial-scale scenarios [32]. The values for the OPV cell efficiency and module lifetime were based on own assumptions albeit within the ranges of Machui et al. [32]: 3.5\% and 5 years (pilot-scale), 5\% 
and 5 years (scale-up), and 10\% and 10 years (industrial-scale). Since the assumed OPV module lifetimes were actually shorter (5/10 years) than the system lifetime (20 years), re-installations were considered as follows: three re-installations for the pilot-scale and scale-up production levels and one re-installation for the industrial production level. For the re-installations, the same module costs were considered taking a conservative approach and assuming no learning curve. In these settings, total OPV costs over the lifetime of the systems were calculated as the sum of (i) module costs, (ii) balance of system costs, (iii) installation/re-installation costs and (iv) operation and maintenance costs: 13.42 $€ / \mathrm{Wp}, 2.72 € / \mathrm{Wp}$ and $1.53 € / \mathrm{Wp}$ for the pilot-scale, the scale-up and the industrial-scale production levels respectively.

Table 3. OPV cost projections based on manufacturing capacity levels: pilot-scale (current state at kW-range capacity), scale-up (at $100 \mathrm{MW}$ capacity), and industrial-scale (at $100 \mathrm{GW}$ capacity). Cell efficiency and module lifetime values were based on own assumptions.

\begin{tabular}{llll}
\hline Costs and parameters & Pilot-scale & Scale-up & Industrial-scale \\
& production & production & production \\
\hline Module cost & $33.74 € / \mathrm{m}^{2}[32]$ & $6.52 € / \mathrm{m}^{2}[32]$ & $5.16 € / \mathrm{m}^{2}[32]$ \\
\hline Device architecture (active layer & Single device & Single device with & Single device with \\
materials) & $(\mathrm{P} 3 \mathrm{HT}: \mathrm{PCBM})$ & carbon electrodes & carbon electrodes \\
& {$[32]$} & $(\mathrm{MH} 301: \mathrm{PCBM})$ & (MH301:PCBM) \\
& & {$[32]$} & {$[32]$} \\
Cell efficiency & $3.5 \%$ & $5 \%$ & $10 \%$ \\
Fill factor $(\mathrm{FF})$ & $37 \%[32]$ & $75 \%[32]$ & $98 \%[32]$ \\
Module lifetime & 5 years & 5 years & 10 years \\
Module cost & $2.61 € / \mathrm{Wp}[32]$ & $0.17 € / \mathrm{Wp}[32]$ & $0.05 € / \mathrm{Wp}[32]$
\end{tabular}


Balance of system cost

Balance of System (BoS) lifetime

Installation/re-installation cost

Operation \& maintenance service

System lifetime

Total OPV system costs
$0.6 \$ / \mathrm{Wp}[31]$

20 years [31]

$0.51 / 0.26 \$ / \mathrm{Wp}[31]$

$0.5 \%$ of modules and BoS costs per year [31]

20 years

$13.42 € / \mathrm{Wp}$
$1.53 € / \mathrm{Wp}$

\subsection{Investment profitability of OPV self-consumption}

To assess the cost-competitiveness of OPV, the Net Present Value (NPV) method was used [52]. In finance, the NPV is a method for evaluating the profitability of an investment by netting the present value of future cash inflows (revenues) and cash outflows (costs) over the period of the investment [52]. In this study, the NPV of investing in an OPV system was calculated based on the initial capital cost of acquiring and installing the OPV system, and the cash inflows achieved by the annual electricity bill savings during the 20-year lifetime of the OPV system, given by Eq. (3).

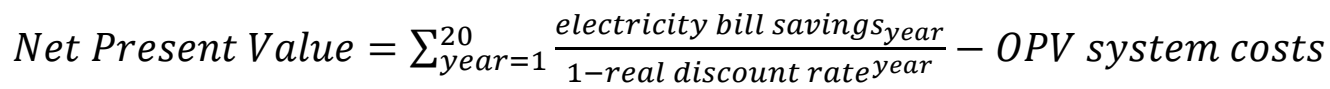

The real discount rate was calculated based on Eq. (4) assuming a 5\% nominal discount rate and the estimated inflation rate over the period of the investment. The inflation rate was taken at $1.97 \%$ for Denmark [47] and assumed to be similar and equal to $2 \%$ for Greece [37].

real discount rate $=\frac{\text { nominal discount rate-inflation rate }}{1+\text { inflation rate }}$ 
If the NPV result was positive, the investment would be profitable, and if otherwise, it would result in a loss. After calculating the NPV of OPV systems for a range of 1-10kWp capacities, the optimal investment solution was given by the highest (positive) NPV result.

\subsection{Further analysis}

An additional prospective analysis was conducted to investigate the extent to which current trends in electricity prices will affect the cost-competitiveness of OPV in the following five years. In this prospective analysis that applies to all PV technologies, gross electricity bill savings (i.e. excluding PV system costs) for a $1 \mathrm{~kW}$ PV system for self-consumption were calculated assuming the installation takes place in 2022 (instead of 2017) with a 20-year investment period up to 2041, under the existing regulatory frameworks in Denmark and Greece. The electricity tariff/fee trends described in Tables 1 and 2 for the period up to 2036 were extended to 2041.

\section{Results and discussion}

\subsection{Self-sufficiency of residential PV systems installed in Denmark and Greece}

Figure 2 shows the self-sufficiency ratios obtained for a residential PV system operating under the existing regulatory frameworks and installed either in Denmark (i.e. termed scenario DK1) or in Greece (i.e. scenario GR1). Depending on PV capacity, the self-sufficiency ratios range from 19\% to $44 \%$ for Denmark, and from $34 \%$ to $100 \%$ for Greece. The large differences in shape and magnitude of the two self-sufficiency curves in Figure 2 mainly reflect the different PV regulatory frameworks of the two countries and more specifically the different period for netting PV generation and 
electricity consumption, i.e. hourly netting in Denmark compared to annual netting in Greece. To investigate the impact of the different netting periods, we calculated the self-sufficiency curve by simulating a hypothetical setting of a 15-min netting period in Greece (i.e. scenario GR2) - see Figure 2). In this hypothetical situation, the self-sufficiency curve for GR2 ranges from $27 \%$ to $50 \%$, showing a trend similar to the curve for DK1, and significantly lower compared to the curve for the GR1 existing annual net-metering, thus confirming the significant influence of the net-metering framework.

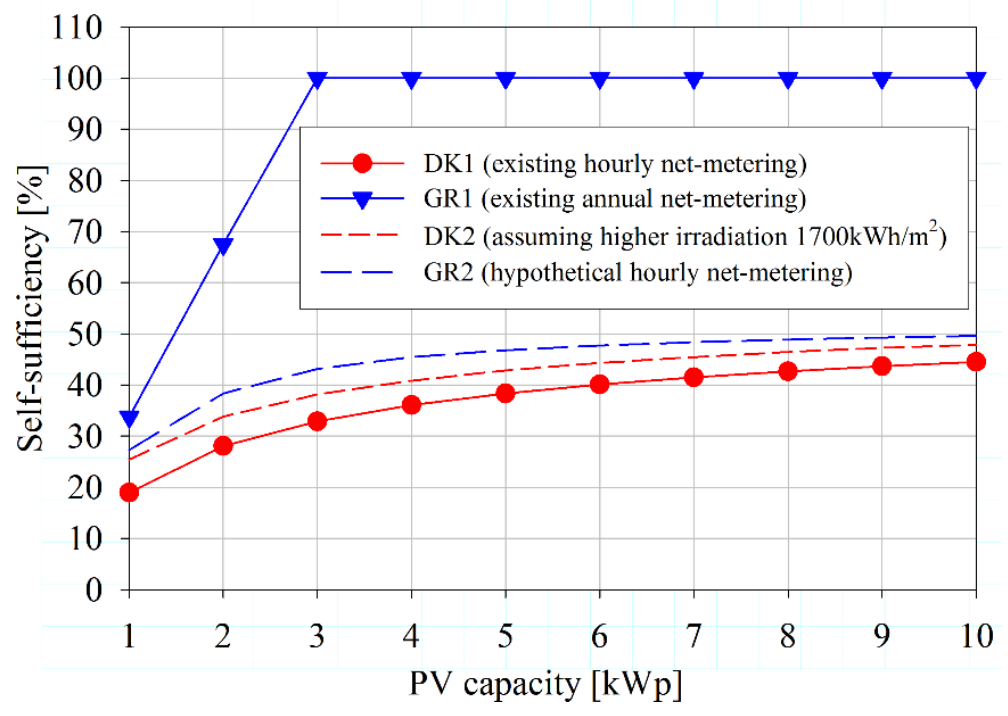

Figure 2. Self-sufficiency potential of residential PV systems with a 4,000kWh/y electricity consumption in Denmark and Greece.

Similar results have been found in the literature. For example, Quoilin et al. [12] calculated the self-sufficiency of residential PV systems installed at several European countries with a 15-min netting period, and reported average self-sufficiency ratios of about 32\% for Denmark, 35\% for Greece, and ranging between $30 \%$ and 37 for all six countries (including Romania, Italy, Portugal and France ) considered in their study. However, Quoilin et al. only considered systems with a ratio 
of annual PV generation to annual consumption of 1:1, instead of calculating the self-sufficiency of residential consumers for a range of PV capacities as conducted in this analysis. To offer comparison with this study, such PV systems (i.e. with an annual PV generation to annual consumption ratio at 1:1) correspond to a self-sufficiency value of $39 \%$ at a $4.8 \mathrm{kWp}$ capacity for DK1 and $43 \%$ at a $3 \mathrm{kWp}$ capacity for GR2 (a direct comparison with the self-sufficiency performance of a PV system calculated based on the existing annual netting period in Greece would be unfit as explained above). Therefore, there is a relatively good agreement between our results and those previously found by

Quoilin et al., albeit with a narrower scope.

\subsection{Key influential factors of PV self-sufficiency performance}

Self-sufficiency performances of PV systems can vary significantly depending on the geographical location because of differences in solar irradiation levels and electricity consumption behaviours/patterns $[9,12,13]$. Previous studies have recommended that more comparable studies are needed to identify similarities and differences and allow application of results to other situations than the studied ones $[9,12,13]$. In our study, three key influential factors were identified: (i) the PV regulatory framework, (ii) the solar irradiation level, and (iii) the electricity consumption profile. We recommend that these factors be systematically characterised and reported along with self-sufficiency results to allow for comparability and further application of the self-sufficiency results (see examples of Greece and Denmark in Table 4).

As described in Section 3.1, the PV regulatory framework can significantly alter the selfsufficiency curves (e.g. see scenarios GR1 and GR2 in Figure 2). To explore the influence of solar irradiation, on PV self-sufficiency results, the self-sufficiency curve for Denmark (i.e. scenario DK1) was recalculated with the assumption that Denmark's solar irradiation was similar to that of Greece 
(i.e. $1700 \mathrm{kWh} / \mathrm{m}^{2}$ instead of $1000 \mathrm{kWh} / \mathrm{m}^{2}$; scenario DK2 in Figure 2). This simulation showed that self-sufficiency results for DK2 would be higher than those for DK1 by 3.3 to 6.5 percentage points (Figure 2), thus indicating a relatively low influence. Finally, the influence of the electricity consumption profiles can be observed in Figure 2 by comparing the self-sufficiency curves of DK2 and GR2 (same solar irradiation at $1700 \mathrm{kWh} / \mathrm{m}^{2}$ and comparable net-metering). The comparison shows that the curve for GR2 demonstrates higher self-sufficiency results than DK2 by about 2 to 5 percentage points, indicating a better match between solar irradiation and the residential electricity consumption in Greece than in Denmark. This is similar to the findings obtained in Denmark when assessing the influence of the electricity consumption profiles on self-sufficiency results of residential, commercial and industrial consumers [53].

Table 4. Characterisation of the base scenarios in Denmark and Greece (DK1 and GR1) with respect to the identified key factors influencing PV self-sufficiency.

\begin{tabular}{lll}
\hline Self-sufficiency and key influential factors & DK1 & GR1 \\
\hline Regulatory framework & Net-metering (hourly) & Net-metering (annual) \\
Solar irradiation level $[\mathrm{kWh} / \mathrm{m} 2 / \mathrm{y}]$ & 1000 & 1700 \\
Electricity consumption profile & Residential 4,000kWh/y & Residential 4,000kWh/y \\
$1 \mathrm{kWp}$ & 19 & 34 \\
$2 \mathrm{kWp}$ & 28 & 67 \\
$3 \mathrm{kWp}$ & 33 & 100 \\
$4 \mathrm{kWp}$ & 36 & 100 \\
$5 \mathrm{kWp}$ & 38 & 100 \\
$6 \mathrm{kWp}$ & 40 & 100 \\
$7 \mathrm{kWp}$ & 41 & 100
\end{tabular}




$\begin{array}{lll}8 \mathrm{kWp} & 43 & 100 \\ 9 \mathrm{kWp} & 44 & 100 \\ 10 \mathrm{kWp} & 44 & 100\end{array}$

\subsection{Gross electricity bill savings from PV self-consumption}

This section presents gross electricity bill savings (i.e. excluding PV system costs) from PV selfconsumption in Denmark and Greece thus offering a technology-neutral perspective. Figure 3 shows the results calculated as the ratio of the NPV of electricity bill savings excluding PV system costs to the NPV of the electricity bill costs over the period 2017-2036 (see Figure A1 in Appendix for absolute values of NPV of electricity bill savings in euros). As illustrated in Figure 3, gross electricity bill savings from residential PV systems reach 75\% in Greece and 32\% in Denmark for a 10kWp PV system. The differences in shape and magnitude of the bill savings curves in Figure 3 can mainly be attributed to the different PV regulatory frameworks of the two countries along with different solar irradiation levels and electricity consumption profiles (see Section 3.2). The comparative analysis of the two countries suggests that Greece offers a financially more attractive market for both residential PV owners and PV manufactures/suppliers than Denmark. Therefore, for emerging PV technologies such as OPV, Greece seems to offer an easier market to enter than Denmark.

Our results can be compared to previous findings from the literature. Figure 3 shows adapted results of PV revenues for Belgium, Germany, Italy, Spain and France retrieved from De Boeck et al. [15], with 2014 as the base year of the investment. To allow comparability with the results in our study, the NPVs of PV revenues for those five countries were calculated based on the original data in De Boeck et al. [15] with the assumptions of a $3 \%$ inflation rate and a $2 \%$ real discount rate. The results obtained for Denmark and Greece are in the same level as the adapted results from De Boeck 
[15] for Spain and Germany, but much lower than results for Belgium, Italy and France. This is because all countries but Spain in De Boeck et al. [15] had PV regulatory schemes with subsidies and/or net-metering allowing for remuneration of excess exported electricity, thus bill savings higher than $100 \%$ could be achieved.

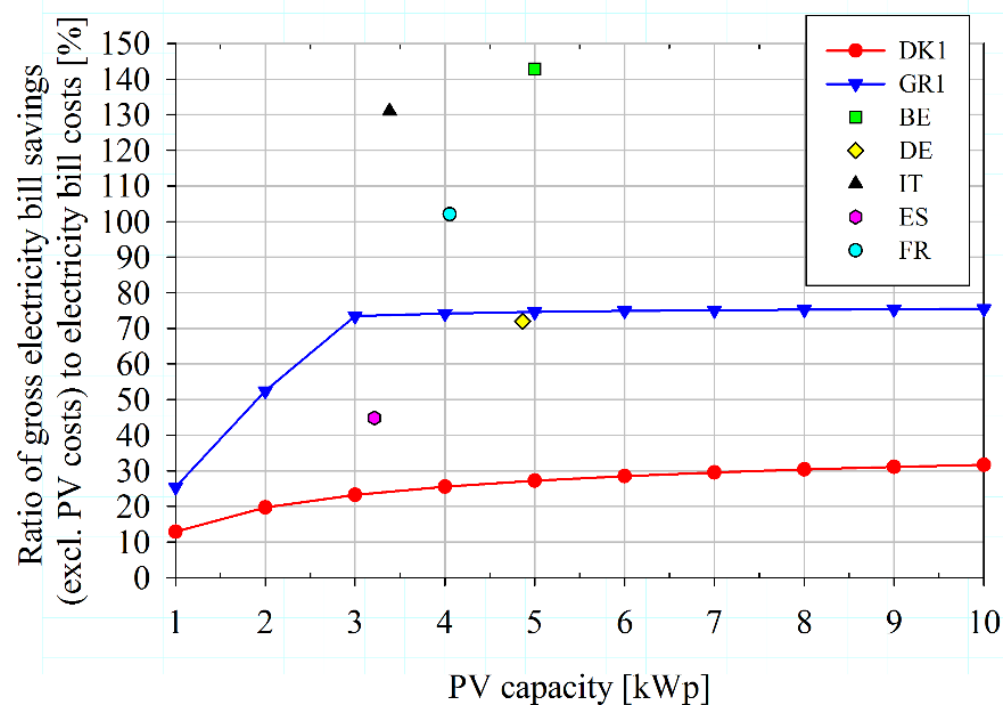

Figure 3. Ratio of gross electricity bill savings (i.e. excluding PV investment costs) to electricity bill costs over the investment period 2017-2036. DK1 and GR1 curves refer to Denmark and Greece investigated in our study; comparative results for BE (Belgium), DE (Germany), IT (Italy), ES (Spain), and FR (France) are adapted from De Boeck et al. [15].

\subsection{Cost-competitiveness of OPV systems for self-consumption}

Figure 4 plots the calculated profitability of investing in an OPV system in Denmark and Greece for residential consumers with annual electricity consumption of $4,000 \mathrm{kWh}$ based for each of the three OPV cost levels (see definitions in Section 2.5). As illustrated in Figure 4a, the NPV results based on the pilot-scale OPV cost level show negative values for both Greece and Denmark regardless 
of the OPV capacity, thus indicating that an OPV total system cost of $13.42 €$ /Wp would be economically unviable to invest in OPV in Denmark or Greece.

In contrast, Figure $4 \mathrm{~b}$ shows some sensibly positive results for both Greece and Denmark. The highest NPV result point of each curve indicates the optimal investment solution for that case. For Denmark, the optimal investment solution was achieved by a $1 \mathrm{kWp}$ OPV system with a $120 €$ NPV achieving a $0.55 \%$ electricity bill reduction. For Greece, the optimal investment solution was achieved by a $2.5 \mathrm{kWp}$ OPV system with a $1504 € \mathrm{NPV}$ achieving a $12 \%$ electricity bill reduction. These results suggest that investing in OPV with a total system cost of $2.72 € / \mathrm{Wp}$, would offer marginal benefits in Denmark but significantly higher gains in Greece.

The industrial-scale setting, as described in Figure 4c, increases the benefits for both countries. For Denmark, the optimal investment solution is achieved by a $1.5 \mathrm{kWp}$ OPV system with a $1432 €$ NPV, now reaching a $6.5 \%$ electricity bill reduction. For Greece, the optimal investment solution is achieved by a $3 \mathrm{kWp}$ OPV system with a $5014 € \mathrm{NPV}$ reaching a $38 \%$ electricity bill reduction. Therefore, the above results indicate that installing an OPV system with a total system cost of 1.53 $€ / W p$ could offer an attractive investment for residential buildings in Greece achieving a electricity bill reduction of over $35 \%$, but not in Denmark where an electricity bill reduction of about $7 \%$ might not be considered sufficiently attractive. 

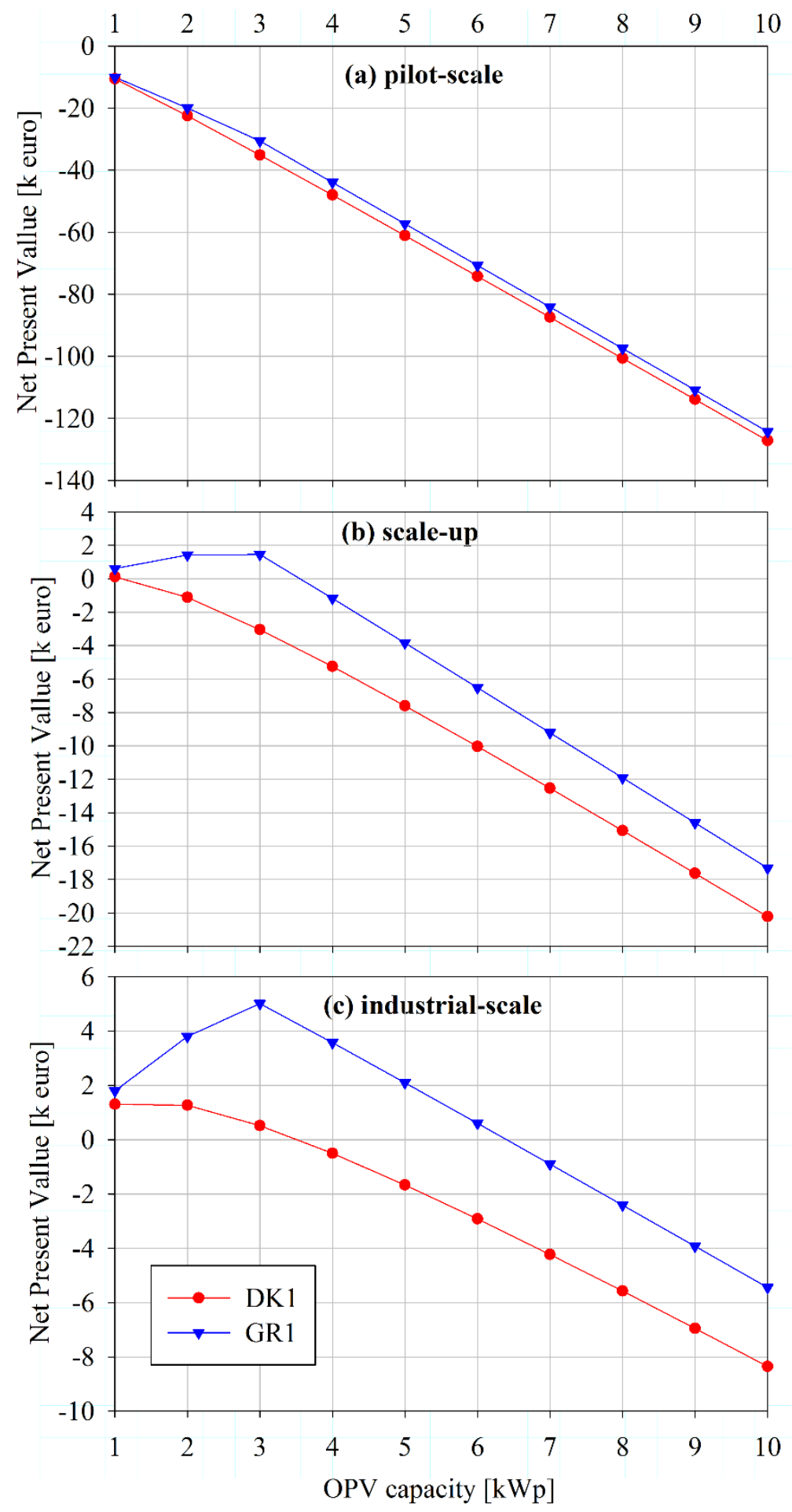

Figure 4. Net present value of OPV self-consumption in Denmark (DK1) and Greece for (GR1) according to the (a) the pilot-scale, (b) the scale-up, and (c) the industrial cost projections (see definitions in Section 2.5 and Table 3). 


\subsection{Target costing for $P V$}

Our methodology was further used from a target costing perspective to determine the required total PV system costs, for which the installed system would achieve a range of electricity bill reductions under current market conditions (e.g. in Denmark or Greece). The results of this target costing approach are relevant to all PV technologies, and not only to OPV.

Figure 5 shows applications of such target costing to Greece and Denmark: DK1 and GR1 curves show the total system costs (left axis) that PV technologies need to reach as a function of the desired electricity bill reduction (horizontal axis). Greece can be observed to offer a more attractive investment environment for residential PV self-consumption than Denmark. For example, the breakeven costs (i.e. at $0 \%$ electricity bill reduction in Figure 5) for PV systems installed in Denmark and Greece were found at $2.83 € / \mathrm{kWp}$ and $3.57 € / \mathrm{kWp}$ respectively. Overall, PV costs for systems installed in Denmark would thus need to be $80 \%$ lower on average than systems installed in Greece to achieve the same level of electricity bill reduction.

Specifically to OPV technologies, the three OPV cost levels of the pilot-scale $(13.42 € / \mathrm{kWp})$, the scale-up $(2.72 € / \mathrm{kWp})$ and the industrial-scale $(1.53 € / \mathrm{kWp})$ scenarios are included in Figure 5 to allow comparison with the DK1 and GR1 curves. By comparing the pilot-scale OPV cost level (assuming it reflects the current status of the technology) with the DK1 and GR1 curves at a desired electricity bill reduction value, the required cost improvements can be identified. Moreover, the intersection points between the up-scale and industrial-scale OPV cost levels and the DK1 and GR1 curves correspond to the optimal investment solutions found in Section 3.4.

In addition to the PV costs, Figure 5 presents the PV system capacities (right axis) that correspond to the specific electricity bill reductions to enable consideration of installation area requirements, which are more relevant to PV technologies with lower power conversion efficiencies such as OPV. 
For example, for Denmark, a $30 \%$ electricity bill reduction could be achieved by a $16.5 \mathrm{kWp}$ PV system, which would however require a roof space as large as $168 \mathrm{~m}^{2}$ assuming a $9.8 \%$ OPV module efficiency (e.g. calculated based on cell efficiency at $10 \%$ and fill factor at $98 \%$ ). However, in the case of Greece, electricity bill reductions of up to $50 \%$ could be achieved by up to $3 \mathrm{kWp}$ PV systems, equivalent to a roof space requirement of $36 \mathrm{~m}^{2}$, thus indicating no serious constraints for OPV systems with an indicative $9.8 \%$ module efficiency.

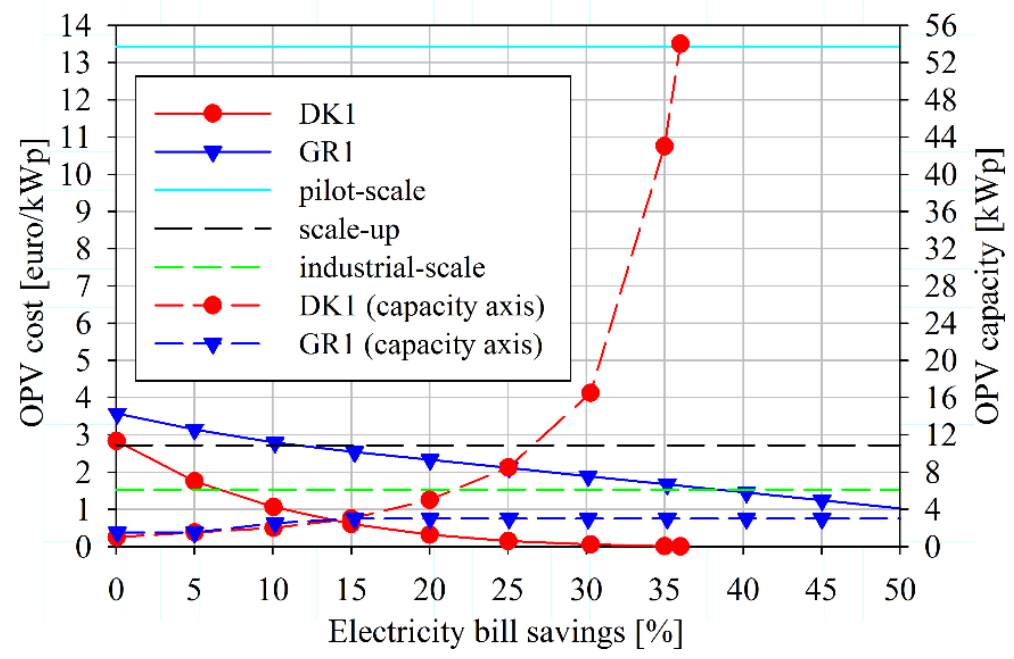

Figure 5. Total PV system costs for which a range of electricity bill savings could be achieved under current market conditions in Denmark (DK1) and Greece (GR1). The pilot-scale, scale-up and industrial-scale OPV cost levels are included for benchmarking.

\subsection{Prospective analysis}

The extent to which current trends in electricity prices will affect the cost-competitiveness of OPV in the following five years were assessed. The evaluation beyond this 5-year period was deemed too uncertain. The period 2017-2022 was investigated assuming no change in the current Danish and 
Greek regulatory frameworks for PV. Using the electricity price projections and assumptions (see Table 1 and 2), gross electricity bill savings for a $1 \mathrm{~kW}$ PV system for self-consumption were calculated assuming the installation takes place in 2022 instead of 2017. For Denmark, in 2022, gross electricity bill savings based on a 1kW PV system for self-consumption were found to vary less than $0.5 \%$ compared to savings in 2017 ; for Greece, savings vary less than $1.5 \%$ compared to savings in 2017. These results demonstrate that, under the current regulatory frameworks, the profit margins and, consequently, the break-even costs, of residential OPV systems for self-consumption are expected to vary marginally until 2022 based on current price projections.

\section{Conclusions and recommendations}

This study assesses the self-consumption of electricity generation from conventional and organic PV systems installed at residential houses in two European countries as indicative case studies, Denmark and Greece. The results show that Greece performs better than Denmark in terms of the self-sufficiency ratio, primarily due to a more favourable PV regulatory scheme, and secondarily due to different solar irradiation levels and the temporal match between the electricity consumption and solar irradiation. Our analysis indicates that the PV self-consumption performance of a given country can vary significantly depending on these three key influential factors: PV regulatory framework, solar irradiation, and, electricity consumption profile. Therefore, when investigating PV selfconsumption, researchers are encouraged to produce new studies with location-specific data rather than rely on already existing studies with assumed similar geographical and policy contexts. Our developed methodology, fully described in Section 2, should be used in this effort, and be applied to other countries by adapting the country- and policy-specific input data. 
The economic analysis of PV self-consumption at residential houses, using the current Danish and Greek PV regulatory schemes as examples, shows that Greece offers a significantly higher profit margin than Denmark, calculated as gross electricity bill savings (i.e. excluding PV costs). This demonstrates that PV technology developers should carefully assess a wide range of countries to identify and prioritise financially attractive environments.

Specifically to OPV technologies, our study evaluates whether OPV systems can offer a profitable investment for households based on electricity self-consumption. The results show that OPV systems developed under an industrial-scale cost setting $(1.53 € / \mathrm{kWp})$ deliver significant electricity bill savings for residential houses in Greece (38\%), whereas these were relatively limited for Danish households (6.5\%), hence likely rendering OPV systems insufficiently attractive for residential houses in Denmark. Therefore, OPV technologies can offer a profitable business opportunity in specific locations, and investors in the renewable energy sector are thus encouraged to pursue scaling up the manufacturing capacity of OPV technologies.

Although not addressed in this work, future similar studies on residential PV systems should further explore how the combination of the PV system with other systems and add-on components, such as battery storage, electric vehicles and heat pumps, may influence the economic profile of the overall energy system of the household. Moreover, moving towards sustainable energy systems, studies should assess the environmental impacts of electricity self-consumption from residential PV systems with battery storage capacity. Most importantly, studies should evaluate whether the addition of battery storage, while necessary to increase utilisation of renewable energy, may contribute to reduction of environmental impacts or not.

\section{Acknowledgements}


Michael Stadler is gratefully acknowledged for supporting Marios Chatzisideris during his research visit at the Lawrence Berkeley National Laboratory, where part of this work was conducted. The authors would like to acknowledge financial support from the Climate Knowledge and Innovation Community platform of the European Institute of Innovation and Technology.

\section{References}

[1] International Energy Agency. Technology Roadmap: Solar Photovoltaic Energy - 2014 edition. OECD Publishing; 2015. doi:10.1787/9789264238817-en.

[2] Boroojeni KG, Amini MH, Nejadpak A, Iyengar SS, Hoseinzadeh B, Bak CL. A theoretical bilevel control scheme for power networks with large-scale penetration of distributed renewable resources. 2016 IEEE Int. Conf. Electro Inf. Technol., vol. 2016-Augus, IEEE; 2016, p. 0510-5. doi:10.1109/EIT.2016.7535293.

[3] Ghadimi P, Kara S, Kornfeld B. Renewable energy integration into factories: Real-time control of on-site energy systems. CIRP Ann - Manuf Technol 2015;64:443-6. doi:10.1016/j.cirp.2015.04.114.

[4] Zhao J, Kucuksari S, Mazhari E, Son Y-J. Integrated analysis of high-penetration PV and PHEV with energy storage and demand response. Appl Energy 2013;112:35-51. doi:10.1016/j.apenergy.2013.05.070.

[5] Amini MH, Frye J, Ilic MD, Karabasoglu O. Smart residential energy scheduling utilizing two stage Mixed Integer Linear Programming. 2015 North Am. Power Symp., IEEE; 2015, p. 1-6. doi:10.1109/NAPS.2015.7335100.

[6] Weniger J, Tjaden T, Quaschning V. Sizing of Residential PV Battery Systems. Energy Procedia 2014;46:78-87. doi:10.1016/j.egypro.2014.01.160. 
[7] European Comision. Best practices on Renewable Energy Self-consumption. 2015.

[8] Masson G, Briano JI, Baez MJ. Review and Analysis of Self-consumption Policies. 2016.

[9] Luthander R, Widén J, Nilsson D, Palm J. Photovoltaic self-consumption in buildings: A review. Appl Energy 2015;142:80-94. doi:10.1016/j.apenergy.2014.12.028.

[10] Bertsch V, Geldermann J, Lühn T. What drives the profitability of household PV investments, self-consumption and self-sufficiency? Appl Energy 2017;204:1-15. doi:10.1016/j.apenergy.2017.06.055.

[11] Beck T, Kondziella H, Huard G, Bruckner T. Assessing the influence of the temporal resolution of electrical load and PV generation profiles on self-consumption and sizing of PV-battery systems. Appl Energy 2016;173:331-42. doi:10.1016/j.apenergy.2016.04.050.

[12] Quoilin S, Kavvadias K, Mercier A, Pappone I, Zucker A. Quantifying self-consumption linked to solar home battery systems: Statistical analysis and economic assessment. Appl Energy 2016;182:58-67. doi:10.1016/j.apenergy.2016.08.077.

[13] Nyholm E, Goop J, Odenberger M, Johnsson F. Solar photovoltaic-battery systems in Swedish households - Self-consumption and self-sufficiency. Appl Energy 2016;183:14859. doi:10.1016/j.apenergy.2016.08.172.

[14] Lang T, Ammann D, Girod B. Profitability in absence of subsidies: A techno-economic analysis of rooftop photovoltaic self-consumption in residential and commercial buildings. Renew Energy 2016;87:77-87. doi:10.1016/j.renene.2015.09.059.

[15] De Boeck L, Van Asch S, De Bruecker P, Audenaert A. Comparison of support policies for residential photovoltaic systems in the major EU markets through investment profitability. Renew Energy 2016;87:42-53. doi:10.1016/j.renene.2015.09.063.

[16] Azzopardi B. Future development promise for plastic-based solar electricity. Prog Photovoltaics Res Appl 2016;24:261-8. doi:10.1002/pip.2652. 
[17] Jean J, Brown PR, Jaffe RL, Buonassisi T, Bulović V. Pathways for solar photovoltaics. Energy Environ Sci 2015;8:1200-19. doi:10.1039/C4EE04073B.

[18] Krebs FC. Fabrication and processing of polymer solar cells: A review of printing and coating techniques. Sol Energy Mater Sol Cells 2009;93:394-412. doi:10.1016/j.solmat.2008.10.004.

[19] Wang Q, Xie Y, Soltani-Kordshuli F, Eslamian M. Progress in emerging solution-processed thin film solar cells - Part I: Polymer solar cells. Renew Sustain Energy Rev 2016;56:34761. doi:10.1016/j.rser.2015.11.063.

[20] Krebs FC, Espinosa N, Hösel M, Søndergaard RR, Jørgensen M. 25th Anniversary Article: Rise to Power - OPV-Based Solar Parks. Adv Mater 2014;26:29-39. doi:10.1002/adma.201302031.

[21] Espinosa N, Laurent A, Krebs FC. Ecodesign of organic photovoltaic modules from Danish and Chinese perspectives. Energy Environ Sci 2015;8:2537-50. doi:10.1039/C5EE01763G.

[22] A. dos Reis Benatto G, Espinosa N, Krebs FC. Life-Cycle Assessment of Solar Charger with Integrated Organic Photovoltaics. Adv Eng Mater 2017;19:1700124. doi:10.1002/adem.201700124.

[23] Tsang MP, Sonnemann GW, Bassani DM. Life-cycle assessment of cradle-to-grave opportunities and environmental impacts of organic photovoltaic solar panels compared to conventional technologies. Sol Energy Mater Sol Cells 2016;156:37-48. doi:10.1016/j.solmat.2016.04.024.

[24] Kalowekamo J, Baker E. Estimating the manufacturing cost of purely organic solar cells. Sol Energy 2009;83:1224-31. doi:10.1016/j.solener.2009.02.003.

[25] Roes AL, Alsema EA, Blok K, Patel MK. Ex-ante environmental and economic evaluation of polymer photovoltaics. Prog Photovoltaics Res Appl 2009;17:372-93. doi:10.1002/pip.891. 
[26] Azzopardi B, Emmott CJM, Urbina A, Krebs FC, Mutale J, Nelson J. Economic assessment of solar electricity production from organic-based photovoltaic modules in a domestic environment. Energy Environ Sci 2011;4:3741. doi:10.1039/c1ee01766g.

[27] Dennler G, Scharber MC, Brabec CJ. Polymer-fullerene bulk-heterojunction solar cells. Adv Mater 2009;21:1323-38. doi:10.1002/adma.200801283.

[28] Powell C, Bender T, Lawryshyn Y. A model to determine financial indicators for organic solar cells. Sol Energy 2009;83:1977-84. doi:10.1016/j.solener.2009.07.009.

[29] Powell C, Lawryshyn Y, Bender T. Using stochastic models to determine financial indicators and technical objectives for organic solar cells. Sol Energy Mater Sol Cells 2012;107:23647. doi:10.1016/j.solmat.2012.06.038.

[30] Mulligan CJ, Wilson M, Bryant G, Vaughan B, Zhou X, Belcher WJ, et al. A projection of commercial-scale organic photovoltaic module costs. Sol Energy Mater Sol Cells 2014;120:9-17. doi:10.1016/j.solmat.2013.07.041.

[31] Gambhir A, Sandwell P, Nelson J. The future costs of OPV - A bottom-up model of material and manufacturing costs with uncertainty analysis. Sol Energy Mater Sol Cells 2016;156:4958. doi:10.1016/j.solmat.2016.05.056.

[32] Machui F, Hösel M, Li N, Spyropoulos GD, Ameri T, Søndergaard RR, et al. Cost analysis of roll-to-roll fabricated ITO free single and tandem organic solar modules based on data from manufacture. Energy Environ Sci 2014;7:2792. doi:10.1039/C4EE01222D.

[33] Mulligan CJ, Bilen C, Zhou X, Belcher WJ, Dastoor PC. Levelised cost of electricity for organic photovoltaics. Sol Energy Mater Sol Cells 2015;133:26-31. doi:10.1016/j.solmat.2014.10.043.

[34] International Energy Agency. Next Generation Wind and Solar Power. IEA; 2016. doi:10.1787/9789264258969-en. 
[35] Kyritsis A, Voglitsis D, Papanikolaou N, Tselepis S, Christodoulou C, Gonos I, et al. Evolution of PV systems in Greece and review of applicable solutions for higher penetration levels. Renew Energy 2017;109:487-99. doi:10.1016/j.renene.2017.03.066.

[36] Energinet.dk. Retningslinjer for nettoafregning af egenproducenter under Engrosmodellen. 2016.

[37] Christoforidis G, Panapakidis I, Papadopoulos T, Papagiannis G, Koumparou I, Hadjipanayi M, et al. A Model for the Assessment of Different Net-Metering Policies. Energies 2016;9:262. doi:10.3390/en9040262.

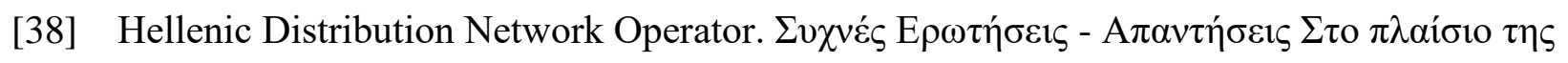

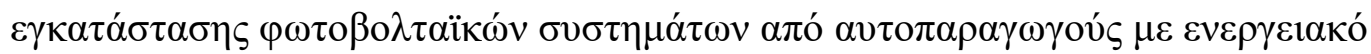

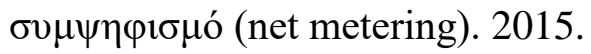

[39] Dansk Energi. Elforbrugspanel 2012. www.elforbrugspanel.dk.

[40] Andersen FM, Larsen HV, Gaardestrup RB. Long term forecasting of hourly electricity consumption in local areas in Denmark. Appl Energy 2013;110:147-62. doi:10.1016/j.apenergy.2013.04.046.

[41] Wang PG, Scharling M, Nielsen KP, Wittchen KB, Kern-Hansen C. 2001-2010 Danish Design Reference Year - Reference Climate Dataset for Technical Dimensioning in Building, Construction and other Sectors. 2013.

[42] European Commission - Joint Research Centre - Institute for Energy and Transport. Photovoltaic Geographical Information System (PVGIS) n.d. http://re.jrc.ec.europa.eu/pvgis/.

[43] Dansk Energi. Elforsyningens tariffer \& elpriser. 2015.

[44] Frischknecht R, Heath GA, Raugei M, Sinha P, de Wild-Scholten MJ. Methodology Guidelines on Life Cycle Assessment of Photovoltaic Electricity, 3rd edition. 2016.

[45] Kitzing L, Katz J, Schröder ST, Morthorst PE, Andersen FM. The residential electricity 
sector in Denmark : A description of current conditions. 2016.

[46] Energistyrelsen. Baggrundsrapport F: Fremskrivning af elprisen. 2015.

[47] Danish Ministry of Finance. Konvergens-program Danmark 2015. 2015.

[48] DONG Energy. Electricity prices 2017. https://www.dongenergy.dk/privat/priser.

[49] Energinet.dk. Transmission grid tariffs 2017. https://www.energinet.dk/El/Tariffer.

[50] Radius. Se nettariffer, netabonnement og tidsopdeling. 2017.

[51] Public Power Corporation. Residential electricity pricing G1 2017.

[52] Akter MN, Mahmud MA, Oo AMT. Comprehensive economic evaluations of a residential building with solar photovoltaic and battery energy storage systems: An Australian case study. Energy Build 2017;138:332-46. doi:10.1016/j.enbuild.2016.12.065.

[53] Chatzisideris MD, Laurent A, Hauschild MZ, Krebs FC. Environmental impacts of electricity self-consumption from organic photovoltaic battery systems at industrial facilities in Denmark. CIRP Ann - Manuf Technol 2017. doi:10.1016/j.cirp.2017.04.100.

\section{Appendix}

Table A1. NPV of gross electricity bill savings (i.e. excluding PV costs) from PV self-consumption in Denmark and Greece for the period 2017-2036.

\begin{tabular}{lll}
\hline PV capacity & NPV of gross & NPV of gross \\
{$[\mathbf{k W p}]$} & savings in DK & savings in GR \\
& [euro] & [euro] \\
\hline 1 & 2840 & 3331 \\
2 & 4332 & 6864 \\
3 & 5114 & 9611
\end{tabular}




\begin{tabular}{lll}
4 & 5627 & 9707 \\
5 & 5993 & 9762 \\
6 & 6275 & 9799 \\
7 & 6499 & 9826 \\
8 & 6685 & 9848 \\
9 & 6838 & 9864 \\
10 & 6970 & 9877 \\
\hline
\end{tabular}

